\begin{tabular}{cc|c}
\hline Tar. Bil. Der. & Journal of Agricultural Sciences \\
& $\begin{array}{c}\text { Dergi web sayfası: } \\
\text { www.agri.ankara.edu.tr/dergi }\end{array}$ & Journal homepage: \\
& www.agri.ankara.edu.tr/journal
\end{tabular}

\title{
The Hydraulic and Economic Performance Analysis of On-Demand Pressurized Irrigation Systems: A Case Study in Turkey
}

\author{
Ezgi KURTULMUŞa, Hakan BÜYÜKCANGAZa, Hayrettin KUŞÇU ${ }^{\text {a }}$, Ali Osman DEMİR \\ ${ }^{a}$ Uludag University, Faculty of Agriculture, Department of Biosystems Engineering, Görükle Campus, 16059 Nilüfer, Bursa, TURKEY
}

\section{ARTICLE INFO}

Research Article $\quad$ DOI: 10.15832/ankutbd.446377

Corresponding Author: Ezgi KURTULMUŞ, E-mail: ezgikaberli@uludag.edu.tr, Tel: +90 (224) 2941617 Received:

10 March 2016, Received in Revised Form: 12 May 2016, Accepted: 17 May 2016

\begin{abstract}
In this study, COPAM (Combined Optimization and Performance Analysis Model) software revealing optimum design possibilities and performance analysis of pressurized irrigation systems, was applied to on-demand pressurized irrigation system in Uludag University Agricultural Application and Research Centre, Bursa, Turkey. The system reliability, hydrant pressure heads, upstream elevation, discharges and pipe diameters related to this irrigation system were analyzed with COPAM software which have a variety of analysis tools. Analysis results showed that there were no deficiencies of performance in the hydrant level of the examined system. Furthermore, pipe diameters of the existing irrigation network were recalculated with COPAM as an alternative scenario and the system performance was reanalyzed based on the new pipe diameters obtained. As a result of this analysis, it wasn't seen any difference in the system performance, although total pipe cost was reduced by $16 \%$. Keywords: Irrigation system performance; Hydrants characteristics; System reliability; Cost analysis

\section{İstek Yöntemiyle İşletilen Basınçlı Sulama Sistemlerinin Hidrolik ve Ekonomik Performans Analizi: Türkiye'den Bir Durum Çalışması}

\section{ESER BILGISİ}

Araştırma Makalesi

Sorumlu Yazar: Ezgi KURTULMUŞ, E-posta: ezgikaberli@uludag.edu.tr, Tel: +90 (224) 2941617

Geliş Tarihi: 10 Mart 2016, Düzeltmelerin Gelişi: 12 Mayıs 2016, Kabul: 17 Mayıs 2016

\section{ÖZET}

Bu çalışmada basınçlı sulama sistemlerinin optimum tasarım olanaklarını belirleyen ve performans analizini yapan COPAM (sınıflandırılmış karakteristik eğriler modeli) yazılımı, Uludağ Üniversitesi Tarımsal Uygulama ve Araştırma Merkezi'nde istek yöntemi ile işletilen basınçlı sulama şebekesine (Bursa, Türkiye) uygulanmıştır. Ele alınan sulama sistemine ilişkin sistem güvenirliliği, hidrant basıç yükleri, kaynak yüksekliği, debi ve boru çapları, geniş analiz araçlarına sahip olan COPAM yazılımı ile analiz edilmiştir. Analiz sonuçları, incelenen sistemde hidrant düzeyinde performans eksikliği olmadığını göstermiştir. Ayrıca, mevcut sulama şebekesinin boru çapları, alternatif bir senaryo olarak COPAM yazılımı ile yeniden hesaplanmış ve elde edilen yeni boru çaplarına göre sistem performansı tekrar analiz edilmiştir. Bu analiz sonucunda toplam boru maliyetinin \% 16 oranında azaltılmasına rağmen, sistemin performansında herhangi bir farklılık görülmemiştir.

Anahtar Kelimeler: Sulama sistem performans1; Hidrant karakteristikleri; Sistem güvenilirliği; Maliyet analizi 


\section{Introduction}

It is known that pressurized irrigation systems have more advantages compared with open channels commonly used in irrigated agriculture. Pressurized irrigation systems provide more productive use of water at farm level and keep losses at minimum level (Barutçu \& Özcan 2011). Therefore, more area can be irrigated with the same amount of water and the measurement of the amount of water conveyed with these systems can be performed more easily and correctly.

On-demand is mostly preferred as operating method for pressurized irrigation systems, because it is based on conveying water to the irrigated area continuously. The system is based on the principle to provide the required amount of water to irrigation networks within appropriate time. These systems can keep water continuously in the valves of piped systems. The advanced technology is generally used in irrigation networks which water is distributed based on on-demand method. Human interference is at minimum level when the system is operated with automation principles in particular. Farmers can control the frequency and duration of irrigation better (Akyol 2012).

One of the most important issues in the design of on-demand irrigation systems is the calculation of the system discharge. These kinds of discharge can change rapidly depending on the crop pattern, climatic conditions, and on-farm irrigation efficiency and the farmers' demands. The development of the system and on-demand operation performance of irrigation systems require to consider flow regimes changing during the project (Lamaddalena 1997). When considered that initial investment costs of pressurized irrigation systems are high, low level savings can even reach to a remarkable level for these systems. Thus, the prevalence of computer programs and ease of use of the presented programs obligate to deal with pressurized irrigation systems within a system approach (Beyribey \& Balaban 1992).

There is a tendency to pressurized irrigation systems in Turkey nowadays. Especially, the design and performance analysis of on-demand pressurized irrigation systems have a great importance in this tendency. Recently, many computer simulation models have been developed to reach this purpose around the world. There are many computer models such as COPAM (Lamaddalena 1997), EPANET (Rossman 2000), GESTAR (Estrada et al 2009), ICARE (CTGREF 1979) and AKLA (Lamaddalena 1997; Lamaddalena \& Sagardoy 2000) developed by different researchers and based on their own modelling principles to fulfill performance analyses of on-demand pressurized irrigation systems. Several studies have been published on this subject. Calejo et al (2008) evaluated the hydraulic performance of the Lucefecit irrigation network using both ICARE and AKLA simulation models. Lamaddalena \& Khila (2012) showed that the characteristic curve of the irrigation network can be obtained using the COPAM software. However, the hydraulic and economic performance analyses of on-demand pressurized irrigation systems have not been sufficiently researched in Turkey. Therefore, the purpose of this study is to reveal optimum design possibilities of the pressurized irrigation systems by applying COPAM model to an ondemand pressurized irrigation system in Turkey for determining the hydraulic system performance and, so, to demonstrate deficiencies by analyzing the performance in terms of system discharge, hydrant pressure heads, pipe diameters of the network and pipe costs.

\section{Material and Methods}

\subsection{The case study network}

The COPAM was applied to the pressurized irrigation network of Göbelye, the Faculty of Agriculture at Uludag University, Bursa (Figure 1). Irrigation area has altitudes of the highest $104.0 \mathrm{~m}$ and the lowest $63.9 \mathrm{~m}$, its average altitude is $85.0 \mathrm{~m}$, and the average slope of the field is $5 \%$. The irrigation water used is supplied from Göbelye Dam which is situated within Uludag University Görükle Campus and has 125 ha irrigation area and the network discharge $217 \mathrm{~L} \mathrm{~s}^{-1}$. Irrigation water is conveyed to hydrants 
with piped irrigation system by pumping from the sluice gate to reservoir located on the highest point of irrigation area by two electro pumps. And, it is then distributed to irrigated area from reservoir with the help of gravity. The pressurized irrigation system is designed to be operated by on-demand method and it has 40 hydrants. The elevation of the existing reservoir above sea level is $140 \mathrm{~m}$. The minimum necessary pressure head of each hydrant is $\mathrm{H}_{\min } 25 \mathrm{~m}$. In the system, 9 of total 40 hydrants have discharges of $5 \mathrm{~L} \mathrm{~s}^{-1}$ and 31 hydrants have discharges of $10 \mathrm{l} \mathrm{s}^{-1}$. There are also 14 nodes in the project. High density polyethylene (HDPE) pipes were used in the system.

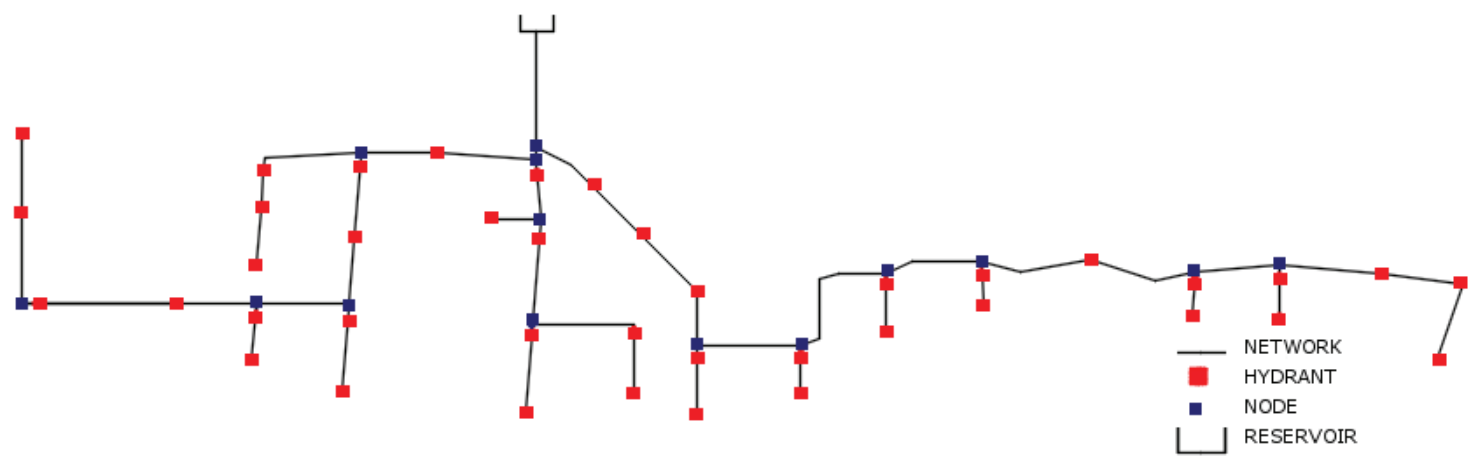

Figure 1- Layout of irrigation network

\subsection{Hydraulic performance analysis}

The COPAM software was used to carry out the hydraulic performance analysis of the system in the study. Also, the pipe diameters of the system were recalculated and the system performance analysis was repeated with COPAM as an alternative scenario.

There are three different configurations of COPAM; calculation of discharge, calculation of pipe diameter, and analysis. There are two modules (Clément and random) in the structure of discharge calculation, a module (optimization) under the structure of pipe diameter calculation and also two modules (configurations and hydrants) under the analysis structure. COPAM performs an optimization with Labye's iterative discontinuous method (ELIDM) extended for several flow regimes models (SFR) for the selection of pipe diameter (Labye 1981; Ait Kadi et al 1990). Further details about COPAM software can be found in Lamaddalena (1997) and Lamaddalena \& Sagardoy (2000).

In this study, it was identified that there are 1000 random hydrant configurations that operate simultaneously depending on the system discharge varying between the range of 50 and $300 \mathrm{~L} \mathrm{~s}^{-1}$. The fact that the number of the examined configurations is high has increased the accuracy of the calculated demand curves. It was identified that the upstream elevation above sea level is $140 \mathrm{~m}$ and the required minimum pressure in hydrants is $25 \mathrm{~m}$ in the system. To analyze by the model; each hydrant on irrigation system and their elevations above sea level, their distances from the initial point and between them were determined in the first. The technical data such as the diameter and length of pipes related to irrigation system were obtained from the irrigation project. The head losses which occurred at the pipes in regard to the positions of the hydrants on the field were calculated for each of the potential discharge values in order to determine the curves of irrigation system. The head losses occurring at the irrigation system were calculated in Equation 1 by using Darcy-Weisbach equation (Lamaddalena \& Sagardoy 2000).

$$
Y=0.000857\left(1+2 \gamma D^{-0.5}\right)^{2} Q^{2} D^{-5} L=u Q^{2} L
$$


Where; $\gamma$, roughness parameter of Bazin (expressed by $\left.\mathrm{m}^{0.5}\right) ; Q$, pipe discharge $\left(\mathrm{m}^{3} \mathrm{~s}^{-1}\right) ; u$, dimensional coefficient of resistance $\left(\mathrm{m}^{-1} \mathrm{~s}^{2}\right) ; L$, the length of pipe $(\mathrm{m})$. The roughness coefficient of Bazin was taken as 0.05 for HDPE pipes used (Lamaddalena \& Sagardoy 2000). AKLA model was used for the reliability analysis of each hydrant with respect to a minimum pressure head $\mathrm{H}_{\min }$ of $25 \mathrm{~m}$.

\subsection{Cost analysis}

In this study, an economic analysis was carried out in order to determine the change in the existing and recalculated total pipe cost according to alternative scenario. For this purpose, calculations were made using both existing and recalculated (by COPAM) pipe diameters and lengths of the irrigation system. Unit cost for every different HDPE pipe diameter was obtained from market research, and the total pipe cost was estimated by multiplying the pipe diameter and the total pipe length.

\section{Results and Discussion}

\subsection{Hydraulic analysis of irrigation system}

\subsubsection{Upstream elevation-discharge analysis}

The indexed characteristic curves for existing system and alternative scenario are given in Figure 2. The system was tested to determine what percentage of the configurations created in different discharges $(50,100,150,200,217,250$ and $300 \mathrm{~L}$ $\left.\mathrm{s}^{-1}\right)$ and elevations $(60,70,80,90,100,110,120$, 130 and $140 \mathrm{~m}$ ) would be met by this system. This test has clearly demonstrated whether the system provides the optimum efficiency with less discharge and upstream elevation under the condition that it meets all of the configurations and the network will be sufficient how to increase the system discharge and upstream elevation under the condition that it meets an insufficent part of the configurations. Figure $2 \mathrm{a}$ indicates the configuration analysis curves of the irrigation system. It was drawn for the upstream elevation $(140 \mathrm{~m})$ corresponding to the available curved system discharge $\left(217 \mathrm{~L} \mathrm{~s}^{-1}\right)$. It is seen that set point is located on the characteristic curve with $\mathrm{P}_{0} 100 \%$ according to the available data. It was found that all of the evaluated configurations were met. That is, it is seen that all system discharge meet $100 \%$ of the discharge required for all of the evaluated configurations and there is no deficiency of discharge in terms of the configuration. For alternative scenario, it is seen that the characteristic curve of set point $\mathrm{P}_{0}$ drops to $95 \%$ approximately as understood in the figure when the system discharge and elevation are compared for 1000 random hydrant configurations in Figure $2 b$. This means that as a high value, $95 \%$ of the examined configurations are fully satisfied.
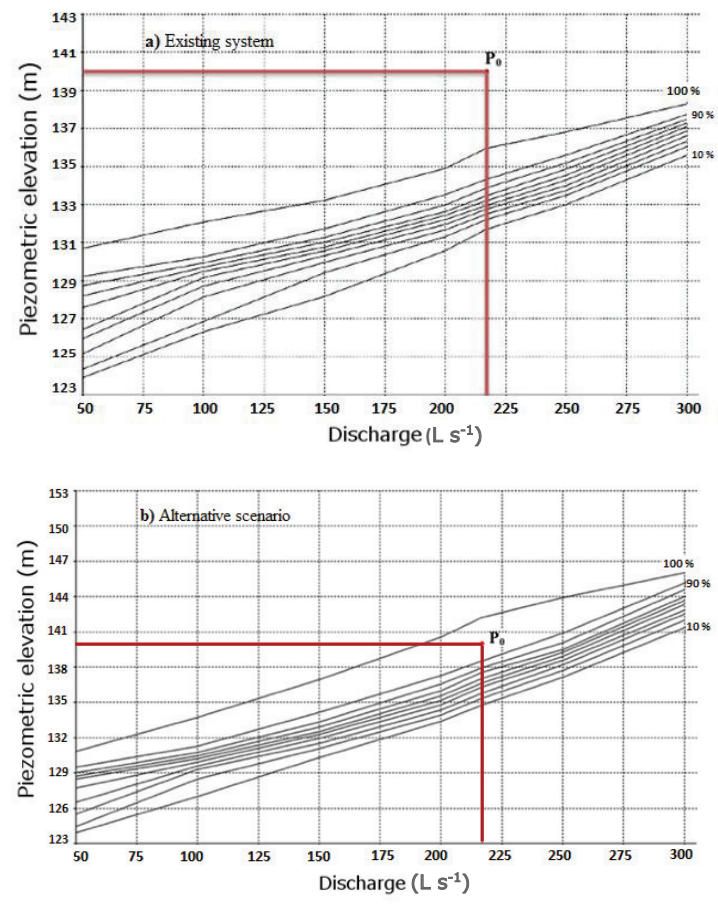

Figure 2- Characteristic curves (for 1000 random hydrant configurations)

\subsubsection{Hydrant analysis (percentage unsatisfied hydrant-discharge)}

The relative pressure values corresponding to hydrant numbers are given in Figure 3. Figure 3 helps to identify the hydrants subject to insufficient pressure and assess the insufficiency range. Figure 
3a demonstrates that this hydrant is satisfactory, in terms of the pressure if its relative pressure value is above zero or this hydrant is unsatisfied if its relative pressure value is below zero. The insufficiency increases when points become closer to -1.0. All hydrants are satisfied in terms of pressure in our study as shown in Figure 3a. The curve obtained by excluding $10 \%$ probability of the results is used to decide whether there is deficit of the relative pressure in a hydrant (Figure 3a). This graphic was also obtained depending on the design discharge and upstream elevation. It was concluded that there was no any problem arising from deficit of the relative pressure in hydrants as shown in Figure 3a which it is also supported by reliability test given Figure $4 \mathrm{a}$.
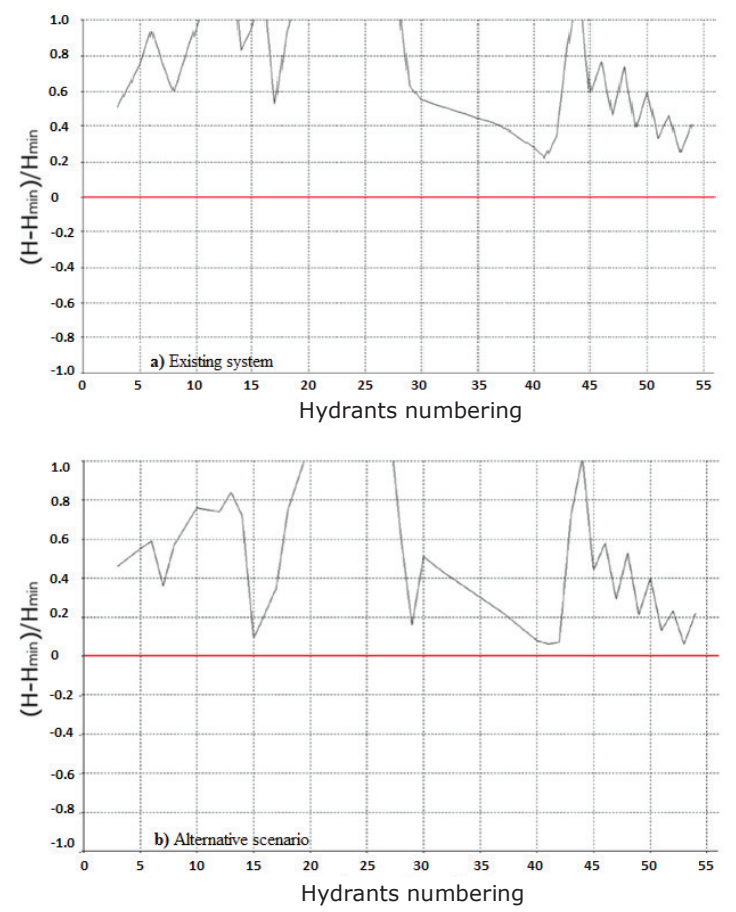

Figure 3- The relative pressure corresponding to the hydrant numbers

The different results of hydrant analysis were obtained for the new pipe diameters calculated according to alternative scenario (Figure $3 b$ ). The relative pressure values corresponding to hydrant numbers are given in Figure $3 \mathrm{~b}$. Figure $3 \mathrm{~b}$ was obtained by excluding $10 \%$ probability of the results of the relative pressure values corresponding to hydrant numbers. The figure was obtained depending on the design discharge and upstream elevation. It is seen that there is scarcely any hydrant which its relative pressure value is below zero in Figure $3 b$ and their relative pressure are above zero to all hydrants formed by excluding $10 \%$ probability in Figure $3 \mathrm{~b}$. This situation shows that there is not unsatisfied hydrant in the system in terms of pressure.

\subsubsection{Reliability test (reliability-hydrant numbers curve)}

Any deficiency on the hydrants is defined as the failure of the system. The failure in a pressurized irrigation system is expressed by the decrease in the minimum pressure head of the hydrant required for suitable field irrigation. The reliability value of the analyzed irrigation network is between 0 and 1 , and it is a desirable condition that this value is to be 1 or closer to 1 . The analyzed irrigation system becomes reliable, because all hydrants have the value of 1 as shown in Figure 4a. The results of the reliability analysis in $217 \mathrm{~L} \mathrm{~s}^{-1}$ discharge and 1000 random configurations associated with the alternative scenario are seen in Figure $4 b$. When the distributions of the hydrant reliabilities were investigated on the graphic, all hydrants except twohydrant were determined to be reliable. According to the results of the reliability analysis, it can be easily stated that there is not the risky hydrant on the system.

\subsubsection{Hydrant analysis in different upstream elevations (percentage unsatisfied hydrant- discharge)}

The location of hydrants on on-demand pressurized irrigation systems, create variable pressure heads and this is essential for pumping station to meet the requirement of minimum pressure head on each hydrant. This situation shows that there are more than one irrigation-demand curve on on-demand pressurized irrigation systems (Planells et al 2001; 

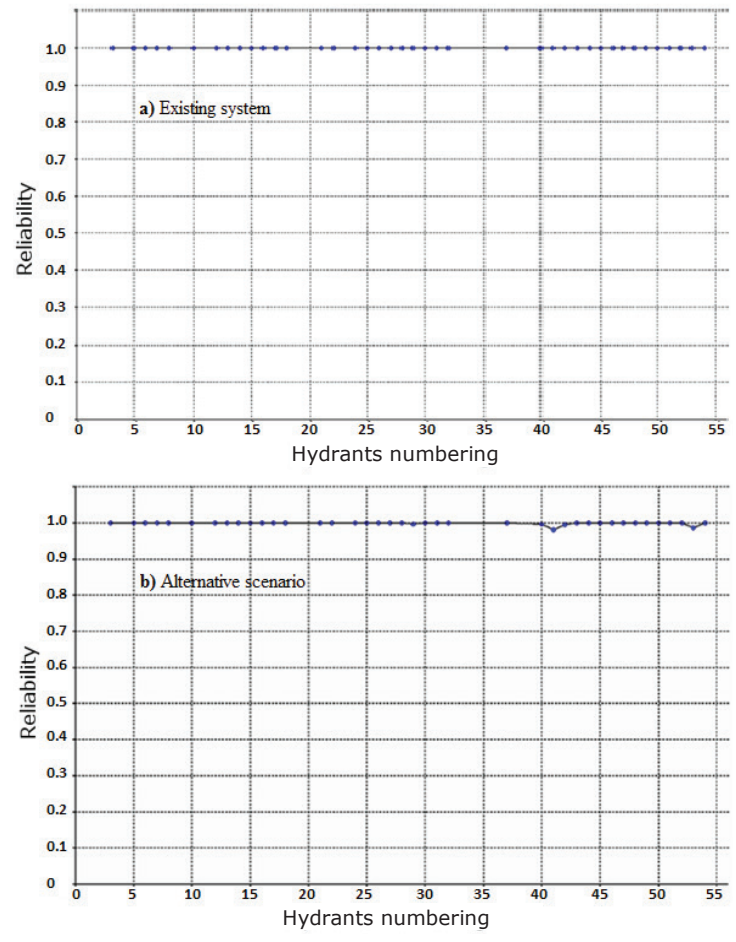

Figure 4- Reliability test (in $217 \mathrm{~L} \mathrm{~s}^{-1}$ discharge and 1000 random configuration)

Pérez et al 2002). Figure 5 was obtained with the selection of $10 \%$ probability curve for points in different elevations ranging from $60 \mathrm{~m}$ to $140 \mathrm{~m}$. This figure has demonstrated the discharge corresponding to percentage change of the unsatisfied hydrants for different upstream elevation values above sea level and 10\% probability of occurrence of PUH (percentage unsatisfied hydrants). This figure provides information whether it is necessary to reduce or increase upstream elevation above sea level to obtain a less PUH value. All range of PUH (100\%-0\%) varies between $90 \mathrm{~m}$ and $130 \mathrm{~m}$ respectively for upstream discharge $217 \mathrm{~L} \mathrm{~s}^{-1}$. Thus, it is seen that all hydrants in the irrigation network are unsatisfied in terms of pressure when upstream elevation above sea level is $90 \mathrm{~m}$ or none of the hydrants are unsatisfied in terms of pressure when upstream elevation is about $130 \mathrm{~m}$ as shown in Figure 5a. As a result, it is realized that adequate pressure can be provided to all hydrants with the
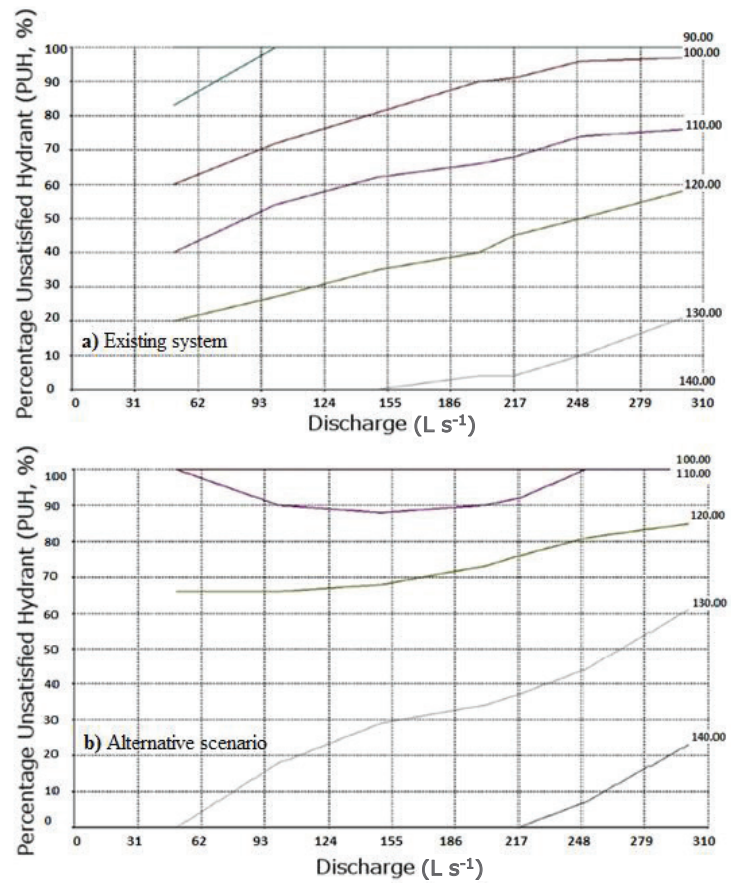

Figure 5- Percentage unsatisfied hydrant (PUH, \%) (for conditions that upstream elevation above sea level ranges from 60 to $140 \mathrm{~m}$ )

available network discharge even if upstream elevation of the irrigation system is designed to be about $130 \mathrm{~m}$.

The model was operated for the different elevations above sea level ranging from $60 \mathrm{~m}$ to $140 \mathrm{~m}$ and the percentage unsatisfied hydrant curves (Figure $5 \mathrm{~b}$ ) were obtained by selecting $10 \%$ probability curve for alternative scenario. All range of PUH for upstream discharge $217 \mathrm{~L} \mathrm{~s}^{-1}(100 \%$ $0 \%$ ) are between $110 \mathrm{~m}$ and $140 \mathrm{~m}$ respectively. Therefore, it is seen that all hydrants in the irrigation network become unsatisfied in terms of pressure in case that upstream elevation above sea level is 110 $\mathrm{m}$ as seen in Figure $5 \mathrm{~b}$ and none of the hydrants become unsatisfied in terms of pressure in the case that upstream elevation is $140 \mathrm{~m}$.

As a result, it was presented that there was not unsatisfied hydrant with $140 \mathrm{~m}$ upstream elevation in the hydrant analysis performed in the same system 
discharge and upstream elevation with smaller pipes in diameter calculated by COPAM without using the available pipe diameters of the irrigation network in the alternative scenario. According to these results, it was observed that pipe diameters reduced by $15 \%$. When the new pipe diameters were calculated in the program instead of pipe diameters of the existing irrigation system, it was seen that there were smaller diameters than the available pipe diameters and almost the same analysis results were obtained with the smaller pipes in diameter. This result is an important finding for evaluating the cost of the system.

\subsection{Economic assessment}

The irrigation system cost, as well as the optimum system design, should be considered for costeffective use of financial resources. The results of an economic evaluation based on pipe diameters and lengths in irrigation system are shown in Table 1. The total pipe cost for existing conditions and alternative scenario was US\$ 570257 and US\$ 477396, respectively. The total pipe cost decreased by recalculation of pipe diameters according to alternative scenario. Based on the results of the present study, a decrease of $16 \%$ in irrigation system cost without being a significant decrease in hydraulic performance, compared with existing condition, could be obtained with alternative scenario. Considering pipe diameters which were computed using optimization techniques of COPAM, it is understood that pipe diameters of the existing system was not selected properly.

\section{Conclusions}

COPAM was useful in evaluating the performance of the pressurized irrigation system Göbelye. It was concluded that the system could operate with $100 \%$ efficiency in the discharge value $\left(217 \mathrm{~L} \mathrm{~s}^{-1}\right)$, its set point. None of the hydrant configurations tested in the study had unsatisfied hydrant, and there was any problem arising from pressure insufficiency for the sufficiency of the system in terms of pressure in the hydrant level. It was found that hydrants located on the irrigation system are reliable. When pipe diameters were calculated with COPAM according to the available other data about the system as if the inspected system had been redesigned, it was reached to a striking conclusion that the system performance could be provided without any unsatisfied hydrant by using smaller pipes in diameter. Thus, it is possible to state that the irrigation network could

Table 1- Cost analysis for pipe diameters

\begin{tabular}{|c|c|c|c|c|c|c|c|}
\hline \multirow[b]{2}{*}{$\begin{array}{l}\text { Pipe } \\
\text { diameter } \\
(\mathrm{mm})\end{array}$} & \multirow[b]{2}{*}{$\begin{array}{r}\text { Pipe cost } \\
\left(\$ m^{-1}\right)\end{array}$} & \multicolumn{2}{|c|}{ Total pipe length $(\mathrm{m})$} & \multirow[b]{2}{*}{$\begin{array}{c}\text { The change } \\
\text { in total pipe } \\
\text { length }(m)\end{array}$} & \multicolumn{2}{|c|}{ Total pipe cost (\$) } & \multirow[b]{2}{*}{$\begin{array}{r}\text { The change } \\
\text { in the total } \\
\text { pipe cost }(\$)\end{array}$} \\
\hline & & $\begin{array}{r}\text { Existing } \\
\text { system }\end{array}$ & $\begin{array}{r}\text { Calculated } \\
\text { with } \\
\text { COPAM }\end{array}$ & & $\begin{array}{r}\text { Existing } \\
\text { system }\end{array}$ & $\begin{array}{r}\text { Calculated } \\
\text { with } \\
\text { COPAM }\end{array}$ & \\
\hline 450 & 175 & 1072 & 538 & -534 & 187600 & 94150 & -93450 \\
\hline 400 & 140 & 1009 & 160 & -849 & 141287 & 22400 & -118887 \\
\hline 355 & 110 & 278 & 1140 & -862 & 30580 & 125391 & 94811 \\
\hline 315 & 87 & 723 & 1044 & 321 & 62924 & 90857 & 27932 \\
\hline 250 & 55 & 738 & 780 & 43 & 40563 & 42926 & 2364 \\
\hline 225 & 44 & 1333 & 1035 & -298 & 58645 & 45556 & -13090 \\
\hline 160 & 22 & 1105 & 1348 & 242 & 24316 & 29645 & 5329 \\
\hline 125 & 14 & 418 & 350 & -68 & 5852 & 4903 & -949 \\
\hline 110 & 11 & 1681 & 1961 & 280 & 18491 & 21568 & 3077 \\
\hline Total & & 8357 & 8357 & 0 & 570257 & 477396 & -92681 \\
\hline
\end{tabular}


be established with lower investment cost $(16 \%)$ in terms of pipe diameter without any loss in its hydraulic performance. It can be stated that COPAM developed to apply the performance analysis of on-demand pressurized irrigation networks is very useful for determining the hydraulic performance of the system and the system design. COPAM allowing the simulation of the possibilities arising from many variables can be used especially in the project designs of the large-scale on-demand pressurized irrigation systems leading to the high investment costs and so the appropriate system designs can be performed. The COPAM can be recommended for the institutions which are involved in designing and operating the pressurized irrigation systems.

\section{References}

Ait Kadi M, Abdellaoui R, Oulhaj A \& Essafi B (1990). Design of large-scale collective sprinkler irrigation projects for on demand operation: A holistic approach. In: Proceedings of the $14^{\text {th }}$ International Congress on Irrigation and Drainage, 30 April-04 May, Rio de Janeiro, Brazil, pp. 59-78

Akyol A (2012). Basınçlı sulama şebekesinde proje debisi hesaplamasına ilişkin yöntem karşılaştırması. Yüksek lisans tezi, Ege Ünivesitesi Fen Bilimleri Enstitüsü (Basılmamış), İzmir

Barutçu F \& Özcan T M (2011). Basınçlı sulama sistemlerinde değişken hızlı pompalarla enerji kazanım olanaklarının araştırılması. Çukurova Üniversitesi Fen ve Mühendislik Bilimleri Dergisi 26(1): 196-208

Beyribey M \& Balaban A (1992). Basınçlı sulama dağıtım sistemlerinin optimizasyonu. Ankara Üniversitesi Ziraat Fakültesi Yayınları, No: 1248, Ankara

Calejo M J, Lamaddalena N, Teixeria J L \& Pereira L S (2008). Performance analysis of pressurized irrigation systems operating on-demand using flow-driwen simulation models. Agricultural Water Management 95: $154-162$

CTGREF (1979). Programme ICARE-Calcul des Caractéristiques Indicées. Note Technique 6, CTGREF Division Irrigation, Aix-en-Provence

Estrada C, González C, Aliod R \& Paño J (2009). Improved pressurized pipe network hydraulic solver for applications in irrigation systems. Journal of Irrigation and Drainage Engineering 135(4): 421430

Labye Y (1981). Iterative discontinuous method for networks with one or more flow regimes. In: Proceedings of the International Workshop on Systems Analysis of Problems in Irrigation, Drainage and Flood Control. 30 November-14 December, New Delhi, pp. 31-40

Lamaddalena N (1997). Integrated simulation modeling for design and performance analysis of on-demand pressurized irrigation systems. PhD Thesis, Technical University of Lisbon, Portugal

Lamaddalena N \& Sagardoy J A (2000). Performance analysis of on-demand pressurized irrigation systems. FAO Irrigation and Drainage Paper No: 59, Roma

Lamaddalena N \& Khila S (2012). Energy saving with variable speed pumps in on-demand irrigation systems. Irrigation Science 30: 157-166

Pérez P C, Alandi P P, Alvarez F O \& Martin Benitez M T (2002). Management and over-exploitation risk of water resources in semi-arid zones. Annual International ASAE Meeting Presentation, Paper No: 022192

Planells P, Tarjuelo J M, Ortega F \& Casanova I (2001). Design of water distribution networks for on-demand irrigation. Irrigation Science 20: 189-201

Rossman L (2000). Epanet 2 user's manual. Environmental Protection Agency, Cincinnati 